\title{
Substance Usage Pre-specified
}

National Cancer Institute

\section{Source}

National Cancer Institute. Substance Usage Pre-specified. NCI Thesaurus. Code C88004.

An indication or description that substance usage was previously determined,

characterized, or detailed. 